\title{
Sabha-parva adapted to Purbo Asmoro's Sesaji Raja Suya: transformation of the concept of power
}

\author{
Dhianita Kusuma Pertiwi ${ }^{1}$, Turita Indah Setyani ${ }^{2}$ and Suma Riella Rusdiarti ${ }^{3}$ \\ \{dhianita.kusuma@ui.ac.id¹, turita.indah@ui.ac.id² \& suma.riella@ui.ac.id ${ }^{3}$ \} \\ 1,2,3 Universitas Indonesia, Depok, Indonesia
}

\begin{abstract}
Rāmāyana and Mahābhārata have been regarded as the sources of Javanese wayang act. The literary adaptation includes textual and ideological transformations as the outcome of acculturation between the Javanese and Indian culture. This paper investigates the textual and ideological transformations on the adaptation of Mahābhārata's second book, Sabha-parva, into Sesaji Raja Suya wayang act by Purbo Asmoro. In this article, Sabha-parva and Sesaji Raja Suya are analyzed as hypo-text and hypertext, respectively, by combining literary adaptation and hypertextuality approach by Gerard Genette and in-depth interview with the author to discuss textual transformations in the characterization of several characters: Yudhisthira, Arjuna, Bima, and Jarasandha. Further analysis on ideological transformation implementing Benedict Anderson and Soemarsaid Moertono's concept of power in the Javanese culture. Research result shows that the textual transformation represents the notion of Jawa-sabrang which constitutes the Javanese concept of power. According to the discussion, this article concludes that the notion of Jawa-sabrang in Sesaji Raja Suya represents the terrorism issues in Indonesia.
\end{abstract}

Keywords: concepts of power, Sabha-parva, Sesaji Raja Suya, transformation.

\section{INTRODUCTION}

Until today, the tradition of wayang purwa in Java maintains its intertextuality with two Indian epics, Rāmāyaña and Mahäbhārata. It can be traced back to the first millennium CE when Indianization occurred in several regions in Southeast Asia, including Nusantara [1]. Indianization has been argued as an important cultural phenomenon when several aspects of Indian culture, such as religion, art, and literature, spread to Nusantara, including Java. It has been noted that the Javanese were able to willingly accept the Indian culture due to some similarities between the two cultures. Sesaji Raja Suya (SRS) is an example of Javanese literary work that combines Indian and Javanese cultural aspects as the adaptation of the second book of Mahābhārata, Sabha-parva (SP).

SP and SRS narrated the preparation and performance of a holy ceremony rajasuya by Pandawa. It is a coronation ceremony to appoint Yudhisthira, the first son of Pandawa brothers, as the supreme king. Meanwhile, a malevolent king named Jarasandha is preparing another kind of ritual, Ludra ceremony, which has a similar purpose as rajasuya, except its evil nature with 
the requirement to kill 100 kings as offering to Ludra. In order to achieve their mission, Pandawa should defeat Jarasandha and free the abducted kings. Despite of the general similarities in the main story and plot, there are several transformations on the adaptation of SP to SRS.

Based on literature review on related studies, textual and ideological transformations on the adaptation of Mahābhärata to Nusantara literature have been analyzed by several previous researchers. Harry Aveling (2018) took a closer look at the "Death of Abimanyu", a story in Mahābhārata by analyzing four different literatures: the original Sanskrit, the Old Javanese version, the Classical Malay rendering, and Modern Indonesian short story "Nostalgia" by Danarto and concluded that the four studied texts propound different ideals from the characterization of Abimanyu [2]. Helen Creese (2018) studied the twelfth-century Old Javanese Baratayuda (the episode of greatwar in the Mahābhārata) and found an additional passage about one of the commanders and his wife. It is a form of transformation as the Old Javanese text gave a name of its own [3]. Another research on the adaptation of Mahäbhārata by Gijs Koster (2019) traced the intertextuality of the Indian epic in Panji story-cycle of Malay tradition. The study concluded that textual transformation especially in religion representation is used as a strategy to engage Muslim society [4].

Regardless the ongoing interest on this subject, transformation on the adaptation of SP to SRS Javanese wayang act is not yet studied. Besides, previous studies on the adaptation of Indian epics to Nusantara literature rarely discussed the ideological transformation related to the concept of power. Therefore, this paper will answer the following questions: (a) how the textual transformation in the adaptation of SP to SRS represents ideological transformation in the concept of power?; and (b) how the ideological context in SRS represents the current social issues in Indonesia? By examining Sabha-parva in The Mahābhārata of Krishna-Dwaipayana Vyasa translated into English Prose from the Original Sanskrit Text (1883-1896) by Pratap Chandra Roy and Sesaji Raja Suya wayang act by Ki Purbo Asmoro.

\section{METHOD}

This paper combines literary adaptation and hyper-textuality to analyze the textual transformation of the studied literary works. Literary adaptation is a form of repetition, but not a replication [5]. Meanwhile, hypertextuality theory acknowledges two kinds of texts: (a) hypotext or source text, and (b) hypertext as the derivation of hypo-text [6]. Furthermore, any texts can be transformed by processes of derivation, editing, reduction, and amplification to form a new text called hypertext [7]. This article examines the textual transformation in the adaptation of SP (hypo-text) to SRS (hypertext) by focusing on the characterization of the protagonist characters: Yudhistira, Bima, and Arjuna; and the antagonist character, Jarasandha. Ideological analysis follows later to investigate the transformation in the concept of power. In addition, the discussion is supported with in-depth interview result with Purbo Asmoro as the writer and performer of the studied wayang act.

\section{RESULTS AND DISCUSSION}

\subsection{Reconstructions of the Protagonist Characters}

In general, Mahābhārata and wayang act constituted similar pattern in the characters' categorization. Both texts acknowledged the Pandawa brothers along with their family members and supporters as protagonists, while Korawa family and the supporters belong to antagonist characters. Regardless of the similarity, there are several differences on the characterizations' construction on the studied text which is mainly influenced by the Javanese cultural values. 
Both texts introduced Yudhistira as the king of Indraprastha and main protagonist character to be coronated as the supreme king in rajasuya ceremony. Yudhistira played a significant role in Sabha-parva during the preparation and performance of rajasuya ceremony. He appeared from the beginning of the story to receive Narada's advice to perform rajasuya, give commands to his brothers, until the day of the ceremony as the leader of the procession. Meanwhile, Yudhistira's role in $S R S$ is significantly reduced. He only appeared at the very last scene before the ceremony processions take place to deliver two short dialogues implying his agreement to the performance of rajasuya on his behalf.

The technique of reduction is used in the hypertext to transform Yudhistira's characterization. It is strongly influenced by the reconstruction of Yudhistira's characterization in the Javanese mythology. In the Javanese mythology, Yudhistira is known as a big-hearted king who acknowledges himself as kawula or servant (of the people). He never stops trying to make other people happy by avoiding arguments and following others' wishes. He prefers to be silent and approve others' behaviors and opinions [8].

The second character, Bima, is constructed in the Indian and Javanese mythology as an extremely strong prince. Both texts depicted him as the slayer of Jarasandha, the main opponent of Pandawa brothers, bare-handedly. The hypertext transforms the character's superpower by amplification technique as can be seen in the narration about the death of Hamsa and Dhimbaka, Jarasandha's faithful followers. The hypo-text illustrated the twin kings' suicide by drowning themselves in Yamuna River [9]. Meanwhile, the hypertext narrated Bima killed Hamsa and Dhimbaka at one time by crushing their heads into each other [10].

In addition, SRS amplifies Bima's superpower with the depiction of aji-aji (supernatural power) mastery. Bima masters three kinds of aji-aji, namely bandung bandawasa, ungkal bener, dan blabak pengantol-antol [10]. Aji bandung bandawasa is a mantra to invite 1000 supernatural beings to help during a battle; aji ungkal bener to bring down mountains and dry up oceans; while aji blabak pengantol-antol will bring more power during a battle [10]. The difference in Hamsa and Dhimbaka's death and the descriptions on aji-aji mastery indicate the transformation in Bima's characterization by the amplification of his physical and supernatural powers.

At the same time, the characterization of Arjuna is transformed using amplification technique in several aspects, including alias, role in the story, and superpower mastery. There are two new aliases for Arjuna used in $S R S$, namely 'Jlamprong' and 'Janaka'. The addition is mainly related to the characterization of Arjuna in Javanese mythology which differs from the Indian version. 'Jlamprong' means 'peacock feathers' which symbolizes Arjuna's handsome, woman-like appearance [11],[12]. Meanwhile, Indian mythology depicts Arjuna as a strong fighter with manly and sturdy body [13]. In addition, his charming appearance allows Arjuna to attract many women to be his wives, represented by 'Janaka' alias which means 'having a lot of wives' [11]. His ability to attract women is narrated in Kedhaton Giribraja scene in SRS when he persuades Dewi Rantamsari, Jarasandha's wife, to leave his husband and come along with him [10]. Those characteristics are unknown in Indian mythology and literary works.

The technique of amplification is also applied in the depiction of Arjuna's superpower mastery. In Prang Kembang scene, Arjuna won over Buta Cakil, Buta Babrah, Buta Punuk and Buta Terong. During this fight, Arjuna does not attack his opponents by his weapon. Instead, he defends himself using gendiran or an imaginary battle which symbolizes the battle between the good and evil in human minds [11],[14]. Therefore, Arjuna's battle in Prang Kembang represents the mastery of spiritual power by a Javanese prince. In addition, Arjuna is described in the hypertext to master aji maundri which he used to help Punakawan enters Jarasandha kingdom [10]. As mentioned previously, the story of aji-aji mastery by Pandawa brothers in the 
hypertext represents the significance of supernatural power in the concept of power in Javanese culture.

The transformations of the three protagonist characters in the hypertext represents the idea of ideal king in the Javanese concept of power. Yudhistira is considered appropriate to be coronated as 'supreme king' due to his dedication to conduct good deeds. Then, the mastery of physical and supernatural powers by Bima makes him an invincible and respected fighter. And lastly, Arjuna is constructed as a good-looking nobleman with spiritual and supernatural power and kind personality. Superpower or kasekten considered one of the essential aspects in the concept of power in Javanese culture as it is regarded as king's legitimation of power [15]. Therefore, textual transformation is applied for the characterizations of protagonist characters in the hypertext to emphasize their qualities as ideal kings in Javanese perspective.

\subsection{Reconstruction of the Antagonist Character}

Textual transformation in the reconstruction of characterization can also be found in Jarasandha. He is the ruler of Magadha or Giribraja kingdom who becomes Pandawa's main opponent in the preparation of rajasuya ceremony. Jarasandha belongs to brahmana rakshasa class in Indian mythology and sabrang king in Javanese mythology [9],[10]. He is characterized in $S P$ and $S R S$ as a king with peculiar childhood experience. He was born by two mothers in two separated bodies. Later, Brihadrata, Jarasandha's father, was unhappy with his son's condition and threw him away in the middle of a forest. Thereafter, a forest spirit named Jara found the baby, combined the two separated bodies until it formed a complete human being.

The technique of editing is applied in the narration of Jarasandha's adult life in the hypertext. In $S P$, Jara returned the baby to Brihadrata after she combined the two separated bodies. Since then, Jarasandha lived happily with his parents until their death and inherited the throne from his father. Meanwhile, SRS described that Jarasandha found out from Jara that he was thrown away as a baby by his parents. Filled with anger, he went to Giribraja kingdom, met his father, then killed him and peeled his father's skin. Jarasandha then made a big drum out of his father's skin and put it on the peak of Cetiyaka mountain. By the death of his father, Jarasandha then sat on the throne. In addition, the hypertext transformed Jarasandha's manner as a father. If $S P$ depicted him as a kind father who trusted his son to continue his kingship, the hypertext narrated his abusive behavior to Jayasetna, his only son.

Further, the technique of amplification is also applied in the hypertext to transform Jarasandha's characterization. SRS added a new character, Dewi Rantamsari, the unhappy wife of Jarasandha. Dewi Rantamsari wanted to leave the kingdom since she has been incarcerated by her husband. Besides, Jarasandha's mastery on aji asmaragama allowed him to enjoy sexual pleasure just by looking at women, including his wife [10]. By this ability on hand, Jarasandha had never pleased his wife by having a sexual intercourse. Jarasandha's mischief is later amplified with the narration about the placement of traps in the surrounding forests of his kingdom to drive away opponents. In addition, the hypertext mentioned that Jarasandha is not only planned to kill one hundred kings as the offering of Ludra ceremony, but also lighted them on fire.

In conclusion, textual transformation of Yudhistira, Bima and Arjuna as protagonist characters and Jarasandha as the main antagonist characters represents the transformation in the concept of power. Three transformation techniques: reduction, editing, and amplification, are applied to emphasize ideal characteristics of the protagonist kings and Jarasandha's impropriety to be categorized as an ideal ruler. The notion of ideal king in the hypertext referred to "Jawasabrang" idea which specifically belongs to the Javanese concepts of power. 


\subsection{The Notion of Jawa-sabrang as Ideological Transformation}

Before the penetration of Indian culture during the Indianization, the Javanese community had already formed their system of culture which include political system and concept of power. The practice of power by ancient Javanese kings and its representation in Javanese literatures indicate the result of acculturation between Indian and Javanese culture that was occurred for several centuries. The classification of human and non-human beings into different categories is familiar in both Indian and Javanese culture. However, the dichotomy of Jawa-sabrang is specifically Javanese epistemology that has been represented in several literary works, including wayang act.

The notion of Jawa-sabrang has been preserved by the Javanese for a long period of time. It is related to the architecture of ancient Javanese nagari or kingdom which was built in concentric formation [16],[17],[18]. Mataram II palace was composed of four regions, namely: (a) negara (capital); (b) nagaragung (main palace); (c) mancanagara (shore); and (d) tanah sabrang (lands across the sea) [17]. Therefore, sabrang refers to any areas outside Java island located across the Java sea. While in fact, this notion is not only related to the geographical identification, as it reflects the way Javanese people value themselves and judge other ethnic groups. The Javanese has their own perception in perceiving their own culture and customs by emphasizing the idea of harmony and respect [].

$S R S$ represents the notion of Jawa-sabrang by the application of textual transformation on the characters' characteristics. The Javanese kings' qualities which include the mastery of three kinds of superpower (physical, spiritual, and supernatural); good-looking appearance; and exemplary behaviors, are reinforced to correspond with the notion of ideal king in the Javanese concept of power. Meanwhile, Jarasandha's identity as a sabrang king is emphasized in the hypertext by the amplification of rude and evil behaviors. Therefore, the textual transformation is used in $S R S$ as a strategy to accentuate the suitability of Javanese kings and princes with the requirements of ideal king in Javanese concept of power and sabrang king inability to comply with it. In addition, the reduction of Yudhistira's role and appearance in the hypertext represents the notion of sendhika dhawuh marang ratu (full devotion towards king) in the Javanese concept of power. Yudhistira's absent during the preparation of rajasuya in SRS implied his full authority over his kingdom and his younger brothers. Arjuna, Bima, and even Kresna, prepared the big ceremony for Yudhistira without his direct intervention because his authority and power had been widely acknowledged and indisputable.

According to Purbo Asmoro, Jawa-sabrang concept in SRS represented one of the social issues in Indonesia, that is terrorism. Jarasandha's ambition to be the supreme king by killing others is the representation of terrorist attacks to the nation's unity and harmony by fundamentalist groups. In general, the Javanese culture upholds the idea of harmony regardless the difference in religion among the people. Jarasandha's identity and actions as sabrang king correspond to foreign, intolerant behaviors shown by non-Javanese people. The ideological transformation in the adaptation of $S P$ to $S R S$ manifested in the notion of Jawa-sabrang represents the current social issues in Indonesia, namely terrorism. Jarasandha's ambition to be the supreme king by killing other people is the illustration of fundamentalist groups' inhumane actions towards the nation's unity and harmony. Thus, the notion of Jawa-sabrang in SRS wayang act by Purbo Asmoro is relevant with the current social issue in Indonesia. Therefore, the depiction of Jawa-sabrang in the hypertext and its moral teaching are relevant with the current social issue in Indonesia. 


\section{CONCLUSION}

Textual analysis by combining literary adaptation and hypertextuality on Yudhistira, Bima, Arjuna, and Jarasandha characteristics in the adaptation of $S P$ to $S R S$ indicated the application of several techniques to transform their characterizations. The transformation techniques found in the hypertext-reduction, editing, and amplification-are applied to emphasize the duality of ideal, Javanese king and unideal, sabrang king. The characters of the Javanese kings are transformed to fulfill the required qualities expected from ideal kings, including exemplary behaviors (Yudhistira), mastery of physical and supernatural powers to fight the opponents (Bima dan Arjuna), and good-looking appearance combined with kindness (Arjuna). On the other hand, Jarasandha's characterization as a sabrang, malevolent king is transformed in the hypertext to emphasize his impropriety to be regarded as an ideal ruler. While the classification of human and non-human beings into separate groups is familiar in both ancient Indian and Javanese mythology, the notion of Jawa-sabrang is specifically an epistemology on the Javanese concept of power. Therefore, the adaptation of $S P$ to $S R S$ is not only constituted by textual transformation, but also ideological transformation on relation to the concept of power. Future research: women's role (genre/object of research)

Acknowledgement. This research is fully supported by Hibah Publikasi Internasional Terindeks Mahasiswa Magister 2019-2020 funded by DRPM Universitas Indonesia No. NKB0998/UN2.R3.1/HKP.05.00/2019.

\section{REFERENCES}

[1] L. Y. Andaya, "The social value of elephant tusks and bronze drums among certain societies in Eastern Indonesia," Bijdr. tot Taal-, Land- en Volkenkd., vol. 172, no. 1, pp. 66-89, 2016.

[2] H. Aveling, "3. Abimanyu Gugur: The Death of Abimanyu in Classical and Modern Indonesian and Malay Literature," in Traces of the Ramayana and Mahabharata in Javanese and Malay Literature, ISEAS-Yusof Ishak Institute Singapore, 2019, pp. 3057.

[3] H. Creese, "6. The death of Śalya Balinese Textual and Iconographic Representations of the Kakawin Bha ${ }^{-}$ratayuddha," in Traces of the Ramayana and Mahabharata in Javanese and Malay Literature, 2019.

[4] G. L. Koster, "5. Ramayana and Mahabharata in Hikayat Misa Taman Jayeng Kusuma," in Traces of the Ramayana and Mahabharata in Javanese and Malay Literature, 2019.

[5] L. Hutcheon, A theory of adaptation. 2006.

[6] J. Herbeck, "Intertexts of the EcologicalAuthor ( s ): Jason Herbeck Source : Journal of Haitian Studies, Vol . 23 , No . 2 ( Fall 2017 ), pp . 81-106 Published by : Center for Black Studies Research Stable URL : https://www.jstor.org/stable/10.2307/26431819," vol. 23, no. 2, pp. 81-106, 2017.

[7] E. Martin, "Intertextuality : An Introduction Intertextuality," vol. 35, no. MAY, pp. 148$151,2011$.

[8] A. Wahyudi, "Transformasi Yudhisthira Mahabarata dalam Tradisi Pedalangan," Resital J. Seni Pertunjuk., vol. 14, no. 1, pp. 71-80, 2018.

[9] K. Vyasa, The Mahabharata of Krishna-Dwaipayana Vyasa Translated into English Prose from the Original Sanskrit Text. Calcutta, Oriental Publishing Co., 1869.

[10] P. Asmoro, Sesaji Raja Suya: Teks Pagelaran Ringgit Purwa Wacucal Tigang Gagrag, 1st ed. Lontar Foundation, 2013. 
[11] Tim Filsafat Wayang, Filsafat Wayang Sistematis, 1st ed. Sekretariat Nasional Pewayangan Indonesia, 2016.

[12] B. R. O. Anderson, Mythology and the Tolerance of the Javanese, 5th ed. Jakarta: Equinox Publishing (Asia) Pte Ltd, 2011.

[13] H. S. Soedjarwo, Rupa dan Karakter Wayang Purwa. Kakilangit Kencana, 2010.

[14] L. Y. Fang, Sejarah Kesusastraan Melayu Kelasik. 2011.

[15] I. Suyanto-Gunawan, "Kekuasaan Jawa: Pandangan Elit Kraton Surakarta dan Yogyakarta," Antropol. Indones., 2018.

[16] N. Keyfitz and Selosoemardjan, "Social Changes in Jogjakarta," Int. J., 2010.

[17] P. Wheatley and S. Moertono, "State and Statecraft in Old Java: A Study of the Later Mataram Period, 16th to 19th Century.," J. Asian Stud., 2006.

[18] B. R. O. Anderson, "I. The Idea of Power in Javanese Culture," in Language and Power, 2019. 